\title{
o corpo feminino, o movimento e a fluidez: As Ninfas em Victor Meirelles e Pedro Américo
}

\section{DANIELA QUEIROZ CAMPOS}

\section{Resumo}

A presente pesquisa aborda a construção corpórea feminina na pintura brasileira do século XIX. O estudo visa problematizar os corpos femininos formulados a partir dos parâmetros da recém instaurada Academia de Artes no Brasil em diálogo com as questões teórica elaboradas por Aby Warburg e Georges Didi-Huberman, em especial com a Ninfa. A Ninfa perpassa a produção de Aby Warburg, que figurara particularmente em sua tese doutoral, seus escritos sobre Domenico Ghirlandaio e seu Atlas Mnemosyne. A Ninfa será principalmente pensada nas pinturas de destacados pintores oitocentistas brasileiros, tais quais: Victor Meirelles e Pedro Américo. 


\section{The feminine body, tha movement and the fluidity: The Nymphs in Victor Meirelles and Pedro Américo}

DANIELA QUEIROZ CAMPOS

\section{Abstract}

This research approaches the female body construction in the nineteenth century in the Brazilian painting. The study aims to problematize the female bodies formulated from the parameters of the newly established Academy of Arts in Brazil in dialogue with the theoretical questions elaborated by Aby Warburg and Didi-Huberman - the nymph, with emphasis. Aby Warburg presents the Nymph particularly in his doctoral thesis, in his writings on Domenico Ghirlandaio and in his Atlas Mnemosyne. The nymph will be mainly analyzed in the paintings of outstanding eighteenth-century Brazilian painters, such as Victor Meirelles and Pedro Américo. 


\section{El cuerpo femenino, el movimiento y la fluidez: Las Ninfas en Victor Meirelles y Pedro Américo}

\section{Resumen}

La presente investigación aborda la construcción corpórea femenina en la pintura brasileña del siglo XIX. El estudio pretende problematizar los cuerpos femeninos formulados a partir de los parámetros de la recién instaurada Academia de Artes en Brasil en diálogo con las cuestiones teóricas elaboradas por Aby Warburg y Georges Didi-Huberman, en especial con la Ninfa. La Ninfa atraviesa la producción de Aby Warburg, que figuró particularmente en su tesis doctoral, sus escritos sobre Domenico Ghirlandaio y su Atlas Mnemosyne. La Ninfa será principalmente pensada en las pinturas de destacados pintores oitocentistas brasileños, tales como: Victor Meirelles y Pedro Américo.

Palabras clave:

Imagen, cuerpo femenino, ninfa 


\section{A Ninfa warburguiniana - a impessoal heroína do Nachleben}

A Ninfa de Warburg nasce em 1892 (DIDI-HUBERMAN, 2015, p. 8), com sua tese doutoral intitulada Nascimento de Vênus e a Primavera de Sandro Botticelli (WARBURG, 2015b), desenvolvida sob a orientação de Hubert Janitschek (RECHT, 2012, p. 8). Alguns anos após a escritura de seu primeiro e único trabalho universitário, Warburg depara-se com sua grande Ninfa diante do afresco o Nascimento de São João Batista (1486-149o) de Domenico Ghirlandaio. E sobre aquela "impetuosa donzela" (WARBURG, 2015a, p. 12) escreve interessante e recentemente publicada correspondência, datada de 19001901 (WARBURG, 2015a). Em seu último e inacabado trabalho, Atlas Mnemosyne, elaborado entre 1926 e 1929 (WARBURG, 2010), as Ninfas estão presentes num sem-número de pranchas. Como exegeta de Aby Warburg, Georges Didi-Huberman também abordou a Ninfa em numerosos trabalhos.

Comecemos com as Ninfas e com as questões colocadas a Aby Warburg por André Jolles. "Quem é ela, donde vêm?" (JOLLES, 2015, p. 8). Estas duas perguntas foram formuladas ainda no final do século XIX, exatamente no ano de 1900, e fazem parte de correspondência trocada entre dois amigos - o linguista André Jolles e o historiador da imagem e da cultura Aby Warburg - acerca da servente do afresco de $O$ nascimento de São João Batista de Domenico Ghirlandaio. A Ninfa de Ghirlandaio figura as paredes da Igreja Santa Maria Novella, em Florença. "Travei conhecimento com ela numa vista semanal a uma igreja [...] Ela reside no coro de Santa Maria Novella, na parede esquerda, segunda fila a partir de baixo, no quadro a direita do expectador" (JOLLES, 2015, p. 6). 
Tratava-se de figura feminina com monocromático vestido branco. Uma servente que portava, em sua cabeça, um cesto de frutos frescos. O afresco faz parte de conjunto pictórico da Capela dos Tornabuoni de Domenico Ghirlandaio. Diante daquela aparição feminina, André Jolles relata ter sido imobilizado pelo movimento da Ninfa.

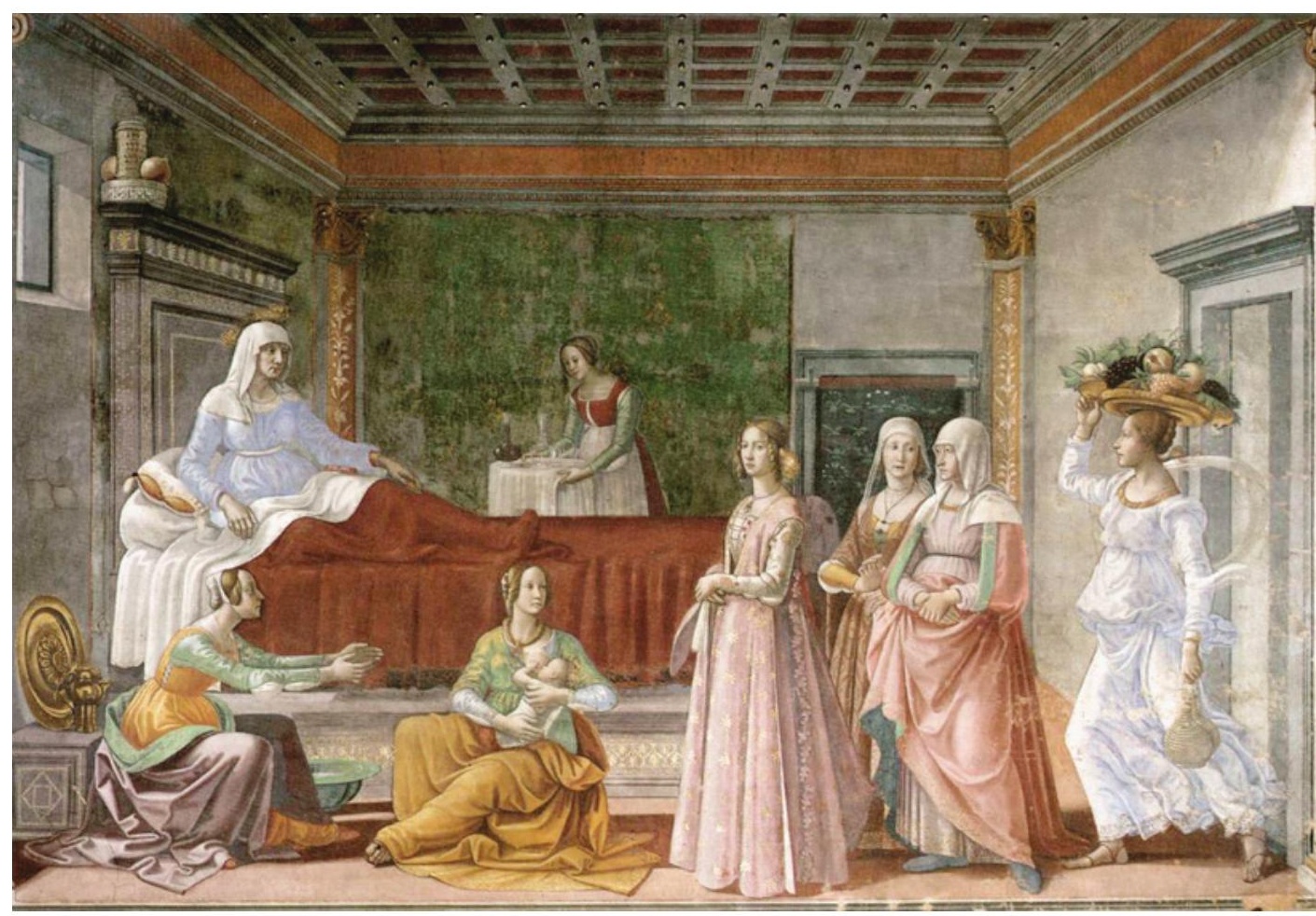

Para Aby Warburg a Ninfa não consistia em nova personagem. Na sua tese doutoral - pela qual recebera título de doutor em filosofia pela Universidade de Estrasburgo, no ano de 1892 (RECHT, 2012, p. 8) - já abordara a Ninfa, inclusive de forma bastante detalhada em III - Motivações Externas dos quadros: Botticelli e Leonardo. Naquela ocasião fora desenvolvida análise acerca da deusa da Primavera, pintada nas duas grandes telas de Botticelli. A deusa apresentaria, nas duas obras, as feições do rosto de Simonetta Vespucci - ilustre figura florentina à época.

Para além de Simonetta Vespucci, a Ninfa figura toda a tese doutoral warburguiniana. Grosso modo, a Ninfa nas obras de Aby Warburg consistia na forma da vida em movimento. E o
Figura 1.

Nascimento de São João Batista, Domenico Ghirlandaio, Afresco, $450 \mathrm{~cm}$ de largura, 1490. Basilica di Santa Maria Novella. 
movimento fora, nada menos, que o tema de sua tese doutoral. O movimento que agitava cabelos e roupagens nas telas de Botticelli fora percebido como corrente dominante desde o início do século XV no norte da Itália. O "injetar vida orgânica a objetos inanimados" (WARBURG, 2015b, p. 34).

"Aby Warburg é provavelmente o primeiro historiador da arte ocidental a ter feito do vento o objeto central de toda uma interrogação sobre a arte da Renascença" (DIDI-HUBERMAN, 2015, p. 63). O drapeado do vento estabelece ferramenta figurativa e patética inestimável aos artistas renascentistas. A chamada brisa imaginária acompanhou o gracioso drapeado das Ninfas, o acessório em movimento (bewegtes Beiwerk). O vento fora apontado, no último capítulo da tese de Warburg, como a causa exterior da imagem. Warburg descobre que esse elemento exterior às figuras - tanto pictóricas, como escultóricas - na Renascença, era indicativo de influência da Antiguidade.

As belas e drapeadas Ninfas da Antiguidade chegaram ao Renascimento italiano pelo mármore esculpido - de arcos do trinfo, estátuas, mas sobretudo ornando sarcófagos. Aproximação de dinâmica e dialética, de realidade exterior e interior, de ornamento e movimento, de forma e intensidade, na arte florentina renascentista, fornecem questões para que Warburg comece a pensar o Pathosformel. O Nachleben, a sobrevivência, atravessa todo conflito. O conflito entre o éthos apolíneo e o pathos dionisíaco, como abordado por Nietzshe em $O$ nascimento da tragédia (NIETZCHE, 2007). Tratar-se -ia de um conflito, de uma instabilidade já identificada na cultura clássica. "O Quattrocento, conclui Warburg, soube apreciar esta dupla riqueza da Antiguidade pagã” (DIDI-HUBERMAN, 2015, p. 41).

Os artistas do Quattrocento reivindicam a Ninfa como uma vitalidade em movimento. Ela não seria apenas uma fórmula iconográfica, mas uma fórmula de intensidade, o poder de fazer visível numa imagem o movimento da vida.

A Ninfa em Warburg opera como a impessoal heroína do Nachleben (DIDI-HUBERMAN, 2002, p. 132). Por hora, parece que podemos creditar a ela a figura de Simonetta Vespucci, por outra, alguém pertencente ao círculo dos Tornabuoni, mas a Ninfa não faz mais do que nos confundir. Tal como a imagem em Warburg, ela não tem intento resolutivo, ela constitui o próprio problema. A figura da Ninfa configura-se nessa relativa indeterminação warburguiniana, tanto que só ganhara nitidamente o nome de Ninfa na correspondência trocada com 
André Jolles. Nos outros textos ela fora muitas, tivera e fora chamada por muitos nomes.

Anos mais tarde, na sala oval de sua biblioteca, Warburg compunha por entre as inúmeras pranchas de seu Atlas Mnemosyne uma porção de Ninfas. "A donzela de pés ligeiros" (WARBURG, 2015a, p. 10) andava, não corria, por entre as imagens que intentavam contar uma história da arte sem palavras.

"A história da ambígua relação entre os homens e as ninfas, é a história da difícil relação dos homens com suas imagens" (AGAMBEN, 2010, p. 44). Giorgio Agamben analisa as Ninfas warburguinianas através do tratado de Paracelso, sendo este familiar a Warburg e a Jolles. Em tal tratado, a Ninfa consiste em objeto da paixão amorosa por excelência.

Aby Warburg atualmente vem destacando-se, sobretudo, no cenário acadêmico. Sua produção data do final do século XIX e início do século XX e não se caracteriza por grandes volumes, mas sim por breves textos, geralmente direcionados a conferências (RECHT, 2012, p. 10). Como trabalho escrito que objetivava as cátedras universitárias produzira apenas sua tese. Contudo, redigira outros sem-número de textos e elaborara sua grande e indescritível biblioteca que dera origem ao Instituto que levara seu nome. Por muito tempo Aby Warburg tivera seu nome vinculado ao Instituto que fundara e fora conhecido como o "pai" da iconologia. Giovanni Careri (2003) sublinha que fora a partir da década de 1960 que ele passara a ser editado, inicialmente traduzido para italiano. Sua primeira bibliografia, escrita por Ernst Gombrich (2015), seria publicada pela primeira vez na Inglaterra em 1970. Contudo, nas duas primeiras décadas do presente século que vislumbramos uma crescente publicação e utilização das obras de Aby Warburg em cenário mundial. Os chamados "herdeiros" warburguinianos são muitos, segundo Marie Anne Lescourret (2014, p. 9), atualmente mais de três mil e cinquenta obras fazem comentários acerca dos trabalhos de Warburg.

\section{A Ninfa em Georges Didi-Huberman - memória, desejo e tempo}

Entre estes muitos herdeiros, aqui o nome de Georges Didi-Huberman merece especial evidência. Primeiramente, porque este artigo perpassa a Ninfa - personagem também abordada e problematizada em vários de seus trabalhos. Em seguida, porque o nome desse historiador da arte e filosofo francês notadamente destaca-se dentre os atuais exegetas de Warburg. 
A Ninfa de Didi-Huberman é a Ninfa warburguiniana por excelência. Seu primeiro contato com ela deu-se através de páginas escritas por Aby Warburg, precisamente durante uma jornada de pesquisa, pós-doutoramento, na Itália da década de 1980. Didi-Huberman abordou notadamente a personagem em: A Imagem sobrevivente. História da arte e tempo dos fantasmas segundo Aby Warburg (2015) e em Ouvrir Vénus: Nudité, rêve, cruauté (1999). E a ela dedicara dois livros: Ninfa Moderna. Essai sur le drape tombe (2002) e Ninfa Fluída (2015).

Para Georges Didi-Huberman na imagem não visualizamos o tempo puro. A imagem é o território do anacrônico, e a Ninfa anda sempre apressada por ele. "Ninfa, Aura, Gadiva... Então para onde elas vão, todas as ninfas desse sutil panteão. Panteão da memória e do tempo, do vento e do drapeado, do luto e do desejo?" (DIDI-HUBERMAN, 2002, p. 11) As Ninfas quase sagradas do Panteão. As eróticas e inquietantes Ninfas foram para muitos lugares em inconstantes tempos. A Ninfa percorre a história da arte como um verdadeiro fóssil em movimento. A donzela de pés ligeiros perpassa e embaralha o tempo.

A aparição que reúne memória, desejo e tempo resistira aos quase sagrados sarcófagos que embelezavam. A aparição resistira como o mármore branco de carrara. Aby Warburg as localizou numa infinidade de encarnações: em têmperas de Botticelli, em afrescos de Domenico Ghirlandaio, naquelas aparições renascentistas as Ninfa já podiam ser percebidas em encarnações que iam de deusa à servente. Nas pranchas do Atlas Mnemosyne ela ganhara outras muitas versões possíveis que perpassavam relevos da Antiguidade, telas renascentistas, cunhagens de moedas, fotografias e ilustrações publicitárias do início do século XX.

Georges Didi-Huberman percebe a Ninfa, tal qual Aby Warburg, como uma fórmula de intensidade capaz de fazer visível numa imagem o movimento da vida. Como não poderia ser diferente, perpassou intensa e extensamente pelas Ninfas propostas por Warburg. Contudo, também proporá outras encarnações possíveis para a divindade menor sem poder instituído.

Em Ninfa Fluída Georges Didi-Huberman (2015) perpassa inúmeras imagens e buscou sua Ninfa pela fluidez de seu movimento. Líquida, quase volátil, Didi-Huberman abordou a Ninfa em desenhos de Leonardo Da Vinci e Victor Hugo, gravuras de Andrea Mantegna e mesmo em alguns tracejos 
do próprio Warburg. Na fotografia de Jacqueline Lamba dans un aquarium (1934) de Rosza Klein, ele destaca uma mulher líquida, e em L'Étole de mer (1928) de Man Ray a própria ótica se transforma em meio fluido (DIDI-HUBERMAN, 2015, p. 156). Dentre tantas encarnações, por vezes perigosas, a Ninfa é marcada como criatura amoral. Didi-Huberman nos lembra que a Servente do Nascimento de São João Batista e a Salomé, que pedira a cabeça decapitada do mesmo santo, são irmãs gêmeas, os dois lados da mesma moeda. Enfim, ele escreve que podemos encontrá-la um pouco por tudo. Sua “[...] Ninfa não é mais do que uma bela estrangeira na história na qual ela faz sua aparição" (DIDI-HUBERMAN, 2015, p. 53).

Nas últimas páginas de Ninfa Fluida ele diz reconhecê-la um pouco por tudo e cita as draperias dançantes dos Parangolés (1960/-) de Hélio Oiticica e os trabalhos de Lygia Clark. Ao findar a leitura de tal livro pensei onde eu também poderia encontrar a Ninfa na arte brasileira. Na ocasião, a primeira imagem que me viera à lembrança, muito mais clássica do que as apontadas no final do livro de Didi-Huberman, fora a tela Moema (1863) de Victor Meirelles. Prontamente interroguei tal escolha. A resposta a esse questionamento deu-se através de outra imagem: A jovem mártire (1855) de Paul Delaroche. O montar dessas duas imagens não me ofereceu solução ou resposta, mas problemas e questionamentos. A Ninfa aqui coloca-se a partir de outra "encarnação possível", como problema. Sendo assim, a partir da imagem de Moema de Victor Meirelles o presente estudo problematiza a encarnação possível da Ninfa em quatro afamadas telas da pintura brasileira do século XIX, sendo duas de Victor Meirelles Moema e A degolação de São João Batista (1855) -, e as outras duas de Pedro Américo - A Carioca (1863) e Judite rende graças a Jeová (1880).

\section{A Ninfa Moema - bela, nua e morta}

Como primeira imagem e como primeiro corpo propõe-se a célebre Moema de Victor Meirelles. Em primeiro plano, o corpo belo e nu de uma jovem mulher. A tela fora pintada no ano de 1863 , durante a estada do artista catarinense na Europa (1853-1861) como bolsista da Academia Imperial de Belas Artes do Rio de Janeiro. Tal estada iniciara-se em 1853 na cidade de Roma, contudo, no ano de 1856, o artista instalou-se em Paris. 
em protagonista, ao menos de seu afamado quadro. Como tantas outras protagonistas pictóricas, a jovem moça fora anteriormente descrita em versos - no poema épico Caramuru (1784) do Frei da Santa Rita Durão (2003).

O poema narra a história - passada no século XVI - do náufrago português Diogo Álvares Correia, que, em terras da América portuguesa, fora denominado de Caramuru. Devida à relação desenvolvida entre o jovem português e os Tupinambás, o chefe oferecera sua filha, Paraguaçu, como esposa. Caramuru residira por anos entre os Tupinambás. As lendas e o poema épico descrevem romanticamente que muitas indígenas se apaixonaram pelo jovem, que mantivera relações com muitas delas. Diogo Álvares Correia retorna a Europa e leva consigo apenas a mulher que casara -Paraguaçu. Muitas daquelas índias Tupinambás jogaram-se ao mar e nadaram atrás da embarcação na qual estava Diogo, entre elas Moema - irmã de Paraguaçu.

No poema épico, Santa Rita Durão já anuncia Moema como Ninfa, ele narra que ela morrera na Bahia com belas Ninfas. Contudo, em versos ela fora apenas coadjuvante. Meirelles apresenta-nos a cena não descrita no poema. Constrói um belo corpo feminino escultórico e o coloca em primeiro plano. Na tela Moema, às referências pictóricas se sobressaem às literárias - do poema épico de Durão.

Tal pintor fizera parte da primeira geração da Academia de Belas Artes do Rio de Janeiro, cuja estrutura baseava-se nas Academias de Arte europeias da época. Meirelles passou anos como bolsista, desta mesma academia, na Europa - em Roma e Paris. Moema, visivelmente, tem suas particularidades dentro desse projeto de construção nacional, típico do Brasil da época. Entretanto, a tela também nos apresenta tema de destaque nas artes europeias: o nu. A pintura do nu feminino destacara-se, sobretudo, a partir do Renascimento Europeu. Para além do corpo nu, a tela Moema aborda uma mulher morta e o exotismo, ambos singularmente em voga no cenário artístico europeu do século XIX.

A tela $A$ jovem mártire, do pintor neoclássico francês Paul Delaroche, figura a imagem de outra mulher morta. Em ambas as telas - a de Meirelles e a de Delaroche - o corpo de uma mulher morta é apresentado na vertical por entre movimentadas águas. Os artistas do romantismo, particularmente tiveram fascínio por representar o mártire (POMEREDE, 2012, p. 63). Delaroche apresenta, em primeiro plano, o cadáver de uma bela jovem romana atirado nas águas do rio Tibre por 
ter recusado abjurar seu rei (PRAT, 2012, p. 76). Seu corpo marca-se por sutil sensualidade, uma bela mulher que parece estar dormindo, flutuando sob as águas transparentes e movimentadas de um rio. A mártire recebera o rosto da mulher de Paul Delaroche e filha de Horace Vernet - Louise Vernet - prematuramente morta, anos antes (BANN, 1999, p. 134). O mesmo rosto pode ser visualizado em outras telas do pintor, tais como: Santa Cecília e os anjos (1836), Louise Vernet sobre sua cama de morte (1845) (BANN, 1999, p. 134-135).

Figura 3.

A jovem mártir, Paul Delaroche. Óleo sobre tela, $171 \times 148 \mathrm{~cm}, 1855$. Musée du Louvre.

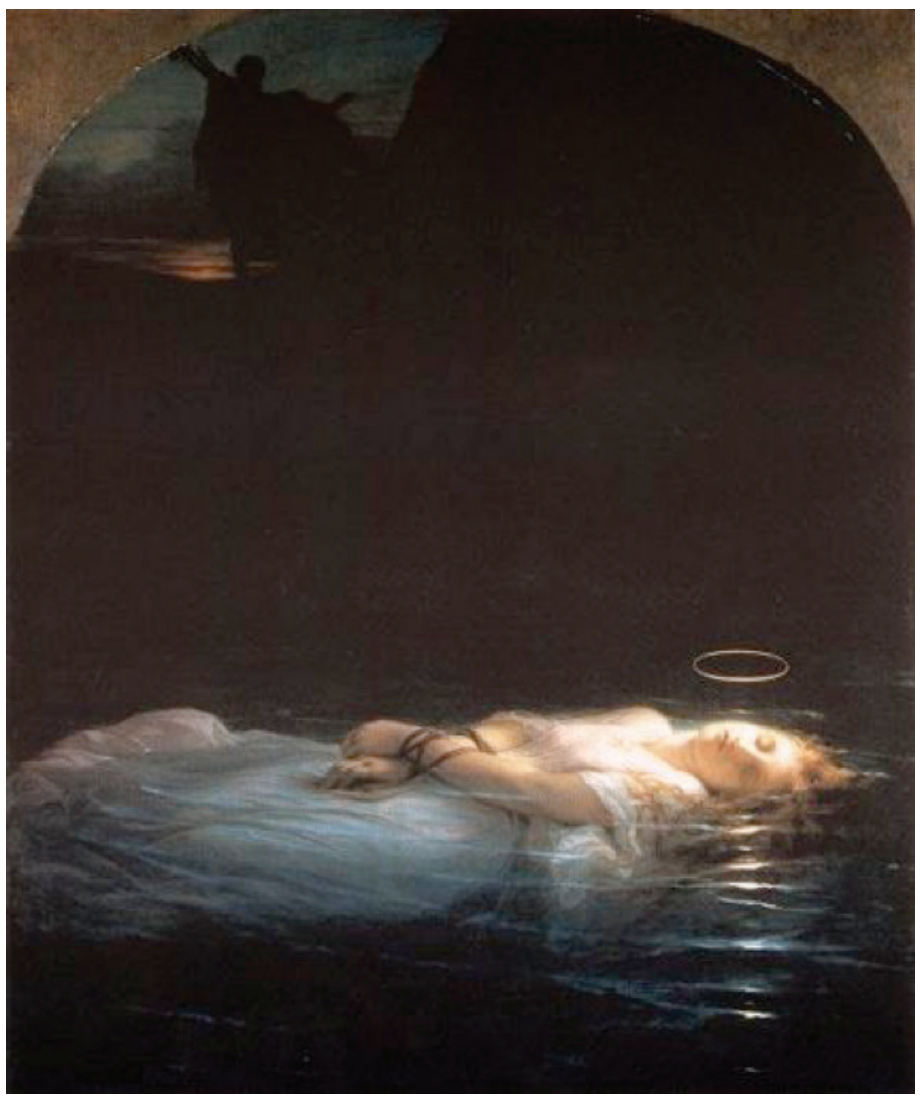

Paul Delaroche configura-se como pintor de referência de Victor Meirelles. Jorge Coli sublinha que, em carta, Araújo Porto Alegre recomenda a Meirelles três pintores em Paris: Antoine-Jean Gros, Horace Vernet e Paul Delaroche (COLI, 2005, p. 54). O pintor brasileiro desejava estudar com Paul Delaroche, o que não se concretizou devido à morte do pintor francês meses após a chegada de Meirelles na França. 
As duas telas em questão - Moema e La jeune martyre - apresentam nítidas disparidades, como coloração, tema, estilo pictórico, apresentação corpórea e gestual. O mar de Delaroche, diferentemente do de Meirelles, é translucido, a composição da tela, especialmente o mar, é escura, salvo a figura feminina de excepcional luminosidade advinda de uma aréola localizada acima da face da moça.

No século XIX, são significativas as apresentações imagéticas de mulheres mortas (DIJSTRA, 1992, p. 140). No século afamado por suas femme fatales (DOTTIN-ORSINI, 1997), sobretudo na França, também vislumbramos incontáveis apresentações imagéticas de mulheres mortas - por exemplo de Ofélia - que muito assemelham-se a descrita obra de Paul Delaroche. O exotismo, pode ser considerado outra marcante tendência da imagem artística à época, sobremaneira visível nas telas dedicadas ao feminino de Delacroix e Ingres.

Mulher com papagaio (1866), de Gustave Courbet, é tela que igualmente abordara tal exotismo. Para Coli (1994), o exotismo e o corpo nu mesclam-se e constituem erotismo na imagem de Courbet, o historiador da arte brasileiro já relacionara tal tela a Moema. A construção corpórea feminina de Courbet destaca-se por sua solidez que ganhara cores e gestos que lhe ofereceram carnalidade. A imagem fora considerada, à época, demasiadamente mundana e de gosto comum. Tanto Mulher com papagaio como Moema são constantemente relacionadas com O Nascimento de Vênus (1863), de Alexandre Cabanel.

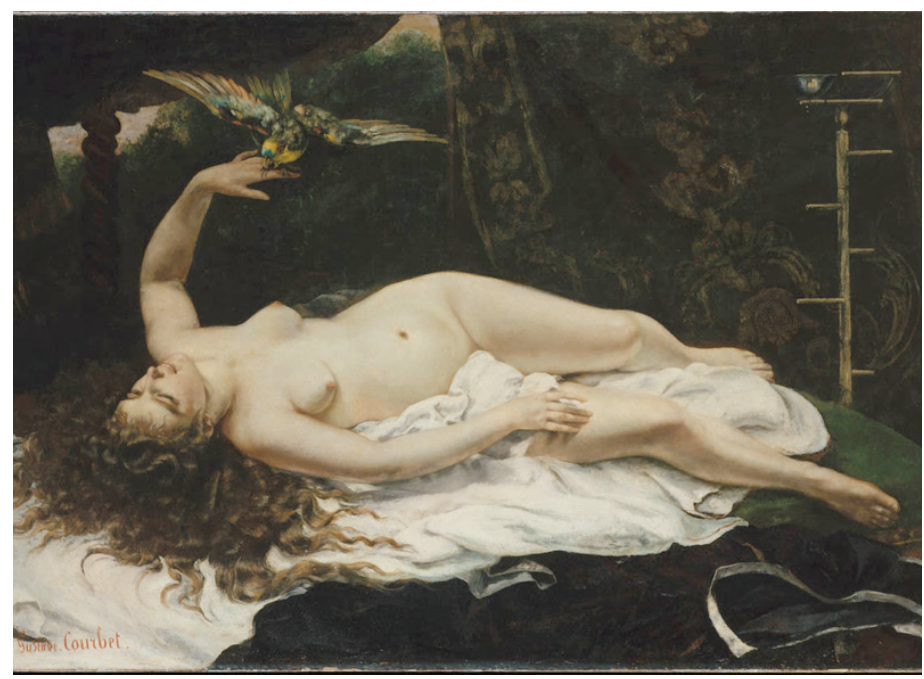

Figura 4.

Mulher com o papagaio, Gustave Courbet. Óleo sobre tela, 129x195 $\mathrm{cm}, 1866$. Metropolitan Museum of Art. 
São visíveis as similitudes e as possibilidades de montagens entre as três telas oitocentistas. Contudo, ensaiemos também montar Moema com outra tela Renascentista, a mais célebre imagem pictórica da deusa do amor, a têmpera o Nascimento de Vênus (1484-1486) de Sandro Botticelli. Nessa imagem, Warburg assinalou o movimento fixado no exterior das margens corpóreas - nos cabelos e nos tecidos (WARBURG, 2015b). Na tela de Meirelles, também podemos perceber esse movimento fixado aos objetos inanimados. O soprar do vento fixa na imagem o movimento, entre a areia e a água do mar.

O corpo desenhado pelo pintor catarinense, tal qual o de Botticelli, constitui corpo escultórico. Visivelmente, o belo corpo da índia não apresenta a mesma coloração do corpo de Vênus de Botticelli - cujo branco nitidamente enuncia o mármore de carrara que na Antiguidade dera forma à deusa do amor. A heroína brasileira figura a tela com a pele em tons terrosos, como se esperaria dela, especificamente naquele momento histórico. De resto, seu corpo obedece a elementos escultóricos bastante claros.

Como cenário, temos um avermelhado mar, o qual leva à areia o corpo morto em questão. A imagem traz-nos uma inquietação provocada pela ausência de qualquer sinal de putrefação no corpo de Moema, ele é perturbadoramente belo. Todavia, o pathosformel 3 que podemos apontar nestas duas imagens - a de Meirelles e a de Botticelli - não estão, necessariamente, em seus primeiros planos, mas nos detalhes. $\mathrm{O}$ soprar do vento que, sai da boca do deus Zéfiros, agitara os elementos inanimados da têmpera de Botticelli fora o mesmo que agitara a figura da servente, da grande Ninfa warburguiniana, no afresco O Nascimento de São João Batista. Na tela pintada a óleo por Meirelles, o vento também agita a cena, ele fora marcadamente colocado entre a areia e a água do mar e assinala o pathos da imagem - que pode ser considerado a morte da heroína, que incrivelmente não está representada no corpo morto. Tal corpo parece figurar apenas um ethos ${ }^{4}$ apolíneo. No movimento fixado no exterior do corpo de Moema visualizamos a tal "imagem da vida em movimento". A tela de Meirelles conjuga muitíssimo bem ethos apolíneo a pathos dionisíaco, o belo ao trágico do qual Warburg, como leitor de Nietzche (2011), tanto enfatizara. A heroína figura essa dualidade, que talvez nem seja tão forte assim, entre o amor e a morte. É uma jovem, uma bela mulher morta, que deixa de ser por amor.

Nas quatro têmperas de $A$ História de Nastagio deli Onesti (1483), Botticelli pinta não uma Vênus que nasce, mas uma 
que eternamente morre (DIDI-HUBERMAN, 1999, p. 55). Tal qual Moema, que tivera como base o poema épico Caramuru (1781) do Frei Santa Rita Durão e O Nascimento de Vênus, que tivera como base textos de Homero e Poliziano, A História de Nastagio degli Onesti fora baseado na novela Decameron (1521-1533), de Boccaccio. A novela de Boccaccio desenvolve narrativa também acerca do amor, como em Caramuru, tal historieta amorosa finda em morte - nossas duas heroínas morrem por amor. A brasileira por ter sido rejeitada pelo homem amado, Caramuru, e a donzela de Boccaccio por rejeitar o homem que a amara, Nastagio degli Onesti. No quarto painel, Botticelli ilustra esta história em qual a jovem aparece nua e morta. Victor Meirelles também pintou a mulher que morreu pelo homem que amara, morreu bastante raivosa com ele, como bem assinalado no poema de Durão.

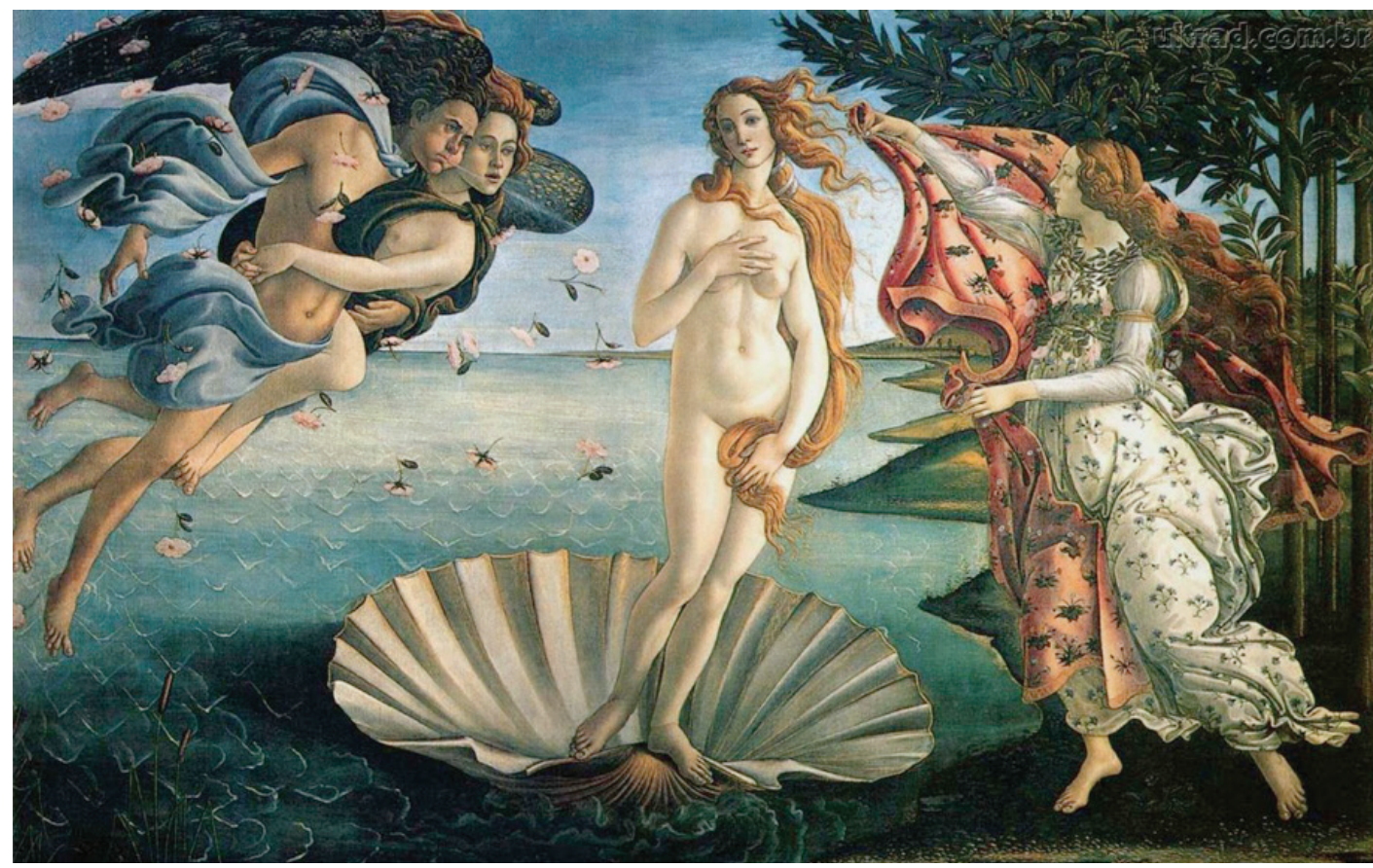

Botticelli conhecera muito bem o trágico das imagens que pintara - em especial em O Nascimento de Vênus -, pois este fora suficientemente descrito tanto em Homero como em Poliziano. A deusa do amor nasce e emerge, por entre as águas do mar Egeu pela da castração de seu pai, Saturno. Esperma e sangue misturados ao agitado mar dão origem a Vênus. A tela

Figura 5.

Nascimento de Vênus, Sandro Botticelli. Têmpera sobre tela, $172,5 \times 278,5 \mathrm{~cm}, 1485$. Galleria degli Uffizi. 
de Botticelli à primeira vista parece ter apenas apresentado a beleza de tal nascimento, porém Warburg assinala que o pathos da cena não se apresenta nos corpos, mas no vento (DIDI -HUBERMAN, 1999). O movimento fora assim apontado por Warburg como a dualidade da Antiguidade que o Renascimento soube tão bem apreciar.

A questão consiste em pesarmos se o Romantismo também apreciou, ou problematizou, esta dualidade. Mas, seguramente ela também é destacada no século XIX, sobretudo em referência a imagens femininas. A atividade warburguiniana nos leva a perpassar a mulher que morre e a mulher que mata como dois lados da mesma moeda.

A nudez de Moema não causara furor à época. A tela pintada em Paris fora, pela primeira vez, exposta no Brasil no Salão em 1866 e não foi criticada pelo teor do corpo nu, ao contrário do que ocorrera com a Carioca (1864), de Pedro Américo um ano antes. Uma das questões que podemos assinalar, advém dos escritos de David Freedberg (2010) que destaca Vênus de Urbino (1538), de Tiziano, por olhar diretamente o expectador. Daniel Arasse (2004) também sinaliza o olhar na mesma tela e credita a ela o erotismo, considerada pelo historiador da arte francês a primeira tela de nudez da arte ocidental. A tela segue a tradição de belos nus feminino horizontalmente apresentados em ambiente privado, normalmente numa cama, que na Renascença eram pintados para figurarem nas paredes do quarto de casamento. Pontuamos brevemente a severa crítica recebida no Salão de Paris de 1865 por Manet em razão da sua tela Olympia (1863) - uma apresentação aos moldes da Vênus de Urbino - por apresentar a imagem de uma prostituta em cena clássica de arte.

\section{A Carioca - o primeiro nu da arte brasileira}

Pois bem, o primeiro nu da arte brasileira - A Carioca provavelmente também se destacou pelo olhar. Talvez também tenha sido o olhar da Carioca a ressaltar seu erotismo que ocasionara crítica, especialmente dos jornais e do mordomo do Imperador à época. A Carioca não olha diretamente seu espectador, mas seu olhar merece especial destaque. A contrário de Moema, que por estar morta, fora apresentada de olhos fechados, a figura de Américo tem enigmático olhar direcionado lateralmente para além da tela. A Carioca tem o mesmo olhar pictórico de muitas Salomés, que aquele século XIX tanto soube apreciar. 
A Carioca fora também pintada em Paris - entre os anos de 1862 e 1863 - onde Pedro Américo residia em decorrência da bolsa de estudos conquistada como prêmio da Academia de Belas Artes. O nu recebera medalha de ouro na Exposição Geral da Academia Imperial de Belas Artes do Rio de Janeiro, no ano de 1865, motivo pelo qual Américo decidiu oferecê-la, como presente, ao Imperador do Brasil - Dom Pedro II. O presente fora recusado pelo Mordomo Mor da Casa Imperial, Paulo Barbosa, por julgar o nu vulgar e escandaloso.

A tela apresenta uma mulher nua sentada, a construção corpórea é bastante curvilínea e voluptuosa, provavelmente também por isso ela tenha sido considerada vulgar à época. O corpo pictórico nu nos parece quase carnal, marca-se pelo Realismo em voga, sobretudo na França, em meados do século XIX, do qual Gustavo Courbet é um dos mais destacados nomes.

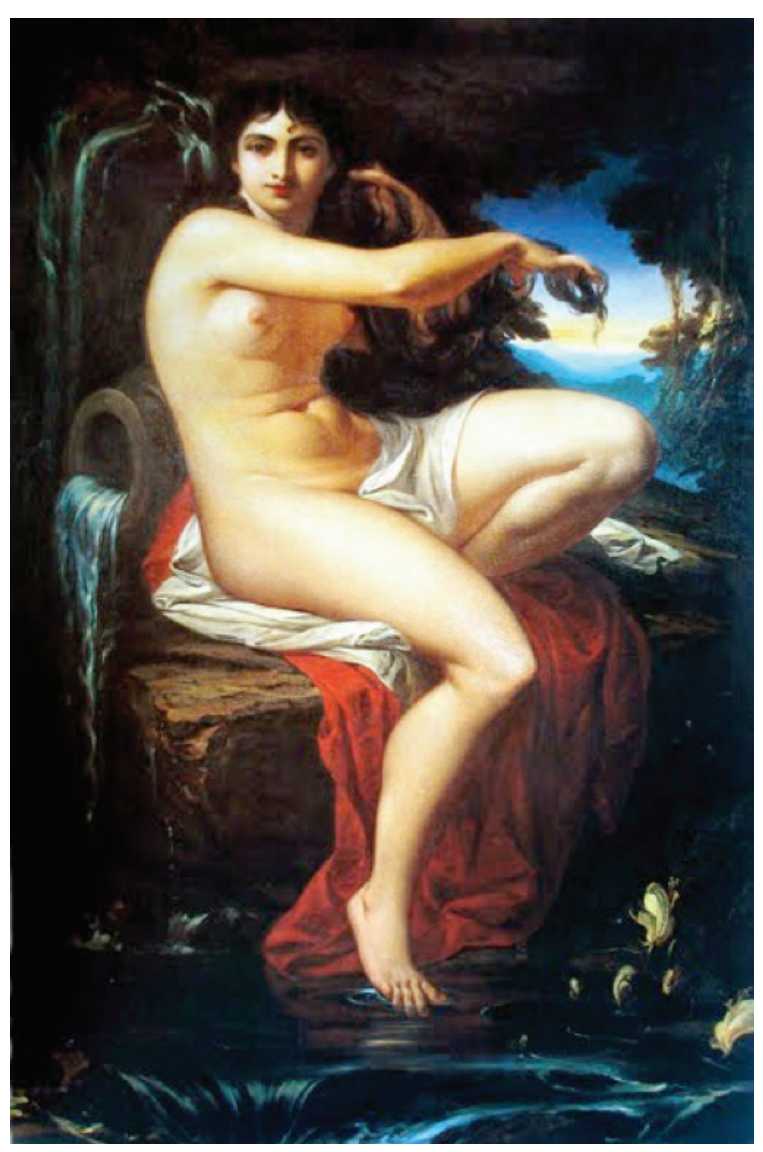

Figura 6.

A Carioca, Pedro Américo. Óleo sobre tela, $205 \times 135 \mathrm{~cm}, 1882$.

Museu Nacional de Belas Artes. 


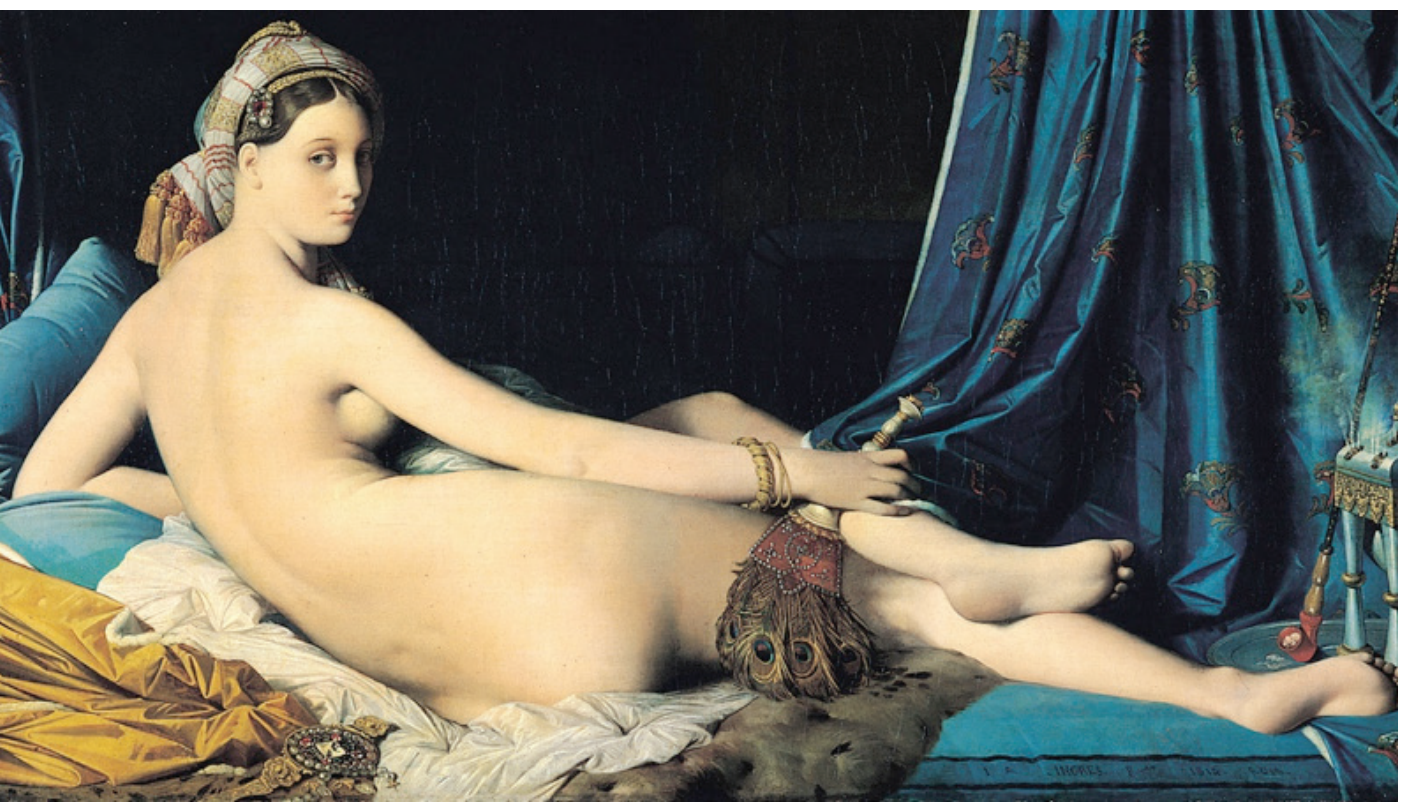

Figura 7.

Grande Odalisca, Dominique Ingres. Óleo sobre tela, 91x162 cm, 1814. Musée du Louvre.
A construção corpórea apresenta pernas e quadris avantajados, tal qual A Grande Odalisca (1814), de Dominique Ingres, afamado por não obedecer aos cânones do corpo anatômico. Em sua Odalisca, Ingres traçou largos e voluptuosos quadris e uma torção de pescoço ímpar. O artista francês abordaria o corpo para além de suas "verdades miméticas". Parece ter preferido o corpo erótico ao corpo anatômico. Sua Odalisca hoje é considerada o primeiro nu da arte moderna, a imagem é inquietamente sedutora.

Ingres fora um dos artistas que Pedro Américo acompanhara em sua estada europeia. Muito de sua Carioca pode ser analisado em conexão com os tantos outros nus femininos do pintor francês, como O Banho Turco (1862) e A Fonte (1856). Em todas estas apresentações corpóreas as curvas e as ondulações eram primazia na construção pictórica de nus.

A tela Carioca fora pintada por Pedro Américo como a alegoria do Rio Carioca que abastecia a cidade do Rio de Janeiro até o século XIX (OLIVEIRA, 2013, p. 1). Contudo, pelos traços e pelas cores da imagem, torna-se difícil não a associar às habitantes daquela cidade.

A imagem feminina fora apresentada em nu frontal, a sensualidade é marcada pelas formas arredondadas, bem como por sua pele morena. A pele castanha da apresentação feminina remarca, e talvez até enalteça, o hibridismo da mulher mestiça 
brasileira. As próprias cores quentes do corpo remetem a uma sensualidade que se difere de muitas apresentações corpóreas femininas europeias daquele momento como, por exemplo, as de Ingres. Cláudia Oliveira já assinala a sensual mulher da tela Carioca como uma Ninfa. "Pedro Américo representa uma mulher local, meio ninfa, meio demônio, meio náiade tropical [...]" (OLIVEIRA, 2013, p. 6). Bem, uma Ninfa não é uma coisa ou outra, ela é tudo isso: mulher, anjo, demónio, náiade. Por tal motivo, a Carioca pode ser analisada como uma encarnação possível da Ninfa na pintura brasileira do século XIX.

Seus expressivos olhos, com uma maldade sedutora, saltam à tela. Para além deles, outro elemento às conectam com tantas apresentações de Salomés: o gesto de sua mão. O braço direito atravessa o troco, sem com isso, por nenhum instante, esconder seus seios. Sua mão parece segurar algo, mas na imagem não localizamos tal objeto. Uma resposta possível seria com vaso, como na apresentação feminina de $A$ Fonte de Ingres, contudo tal vaso na cena de Américo figura atrás do corpo feminino, entre as costas deste corpo e a cadeira onde ele está colocado. Por detrás do braço e da mão figura uma luminosa e bela paisagem.

$\mathrm{Na}$ imagem parece ausentar algo, muito provavelmente uma cabeça. Se os olhos da Carioca se direcionam ligeira e lateralmente para o exterior da tela, tais como os das Salomés e Judites de Lucas Cranach, a gestualidade assemelha-se a da tela Aparição (1876), de Gustave Moreau e Salomé (1900), de Pierre Bonnaud. O gesto da mão direita da Carioca nos dá a impressão de que ela está segurando ou apontando para uma cabeça decapitada.

Um drapeado tecido perpassa parte do quadril da apresentação feminina na mesma tela. A draperia branca e vermelha relaciona a obra com a célebre Vênus adormecida (1500), de Giorgione, que servira de base para tantos notáveis nus femininos, como: Vênus de Urbino e Olympia. O branco e o vermelho marcam os dois grandes fluídos desse corpo feminino: o branco do leite e vermelho do sangue (DIDI-HUBERMAN, 2013b). $\mathrm{O}$ leite materno e o sangue menstrual que assinalam esse feminino não se mesclam na drapearia de Américo, se separam, balizam a eterna dicotomia feminina reafirmada na imagem.

A primeiro nu pictórico da arte brasileira relaciona-se a outros tantos de uma história da arte ocidental. O corpo feminino nu pode ser apontado como uma quase constância em apresentações imagéticas de uma pluralidade de tempos históricos (CLARK, 1956). Ele fora expresso de formas plurais, e 
vem sendo ensaiado desde pequeninas estátuas de terracota que datam da Antiguidade. Os escritos sobre a forma que essa nudez fora expressa, representam igualmente uma constante. Os antigos gregos foram os primeiros a escrever e a teorizar sobre elas, especialmente Platão (2009) em Banquete.

Os motivos pelos quais a nudez de Moema não ocasionara tanta reprovação quanto o da Carioca podem ser muitos. Mas a crítica da época, parece-nos colocar diante de uma antiga questão da imagem do nu, que advém da de Platão: a Vênus celestial e a Vênus vulgar. As esculturas de Vênus assinalavam uma beleza que, como escrevera Platão, fora ora celestial, ora vulgar. Kenneth Clark (1956), embasado em tais teorias platônicas aborda que o nu feminino pode, muitas vezes, ser considerado vulgar, feio e até mesmo pornográfico; e relata os esforços da arte europeia em converter a imagem de Vênus em celestial. Georges Didi-Huberman aponta que esse projeto neokantiano, enfatizado por Clark, busca a separação de forma e desejo, diante de um nu dever-se-ia manter o juízo e esquecer a carne (DIDI-HUBERMAN, 1999). Os esforços para dessexualizar e desculpabilizar a imagem do nu enfatiza o desejo suscitado por ela. David Freedberg (2010) aborda a excitação de pessoas ao contemplarem pinturas e esculturas. Durante a cristandade medieval imagens de Vênus foram mal vistas por instigarem pensamentos e ações adúlteras. Todavia, Jean-Claude Schimitt (2007) aborda imagens de mulheres do cristianismo que mesmo estando vestidas passaram a exercer grande poder de sexualidade. Eram Virgens que davam leite e imagens de Maria, que tal quais as imagens pagãs, protagonizavam as historietas de alianças.

\section{Salomé e Judite - Ninfas a caçar cabeças}

Dentre estes corpos femininos que tanto suscitaram desejo, a personagem bíblica da Salomé merece especial destaque naquele século XIX. Para além da própria Salomé, outras caçadoras de cabeças perpassaram a pintura daquela época. As imagens artísticas de então eram repletas de cadáveres. Victor Meirelles e Pedro Américo apresentaram cada qual, sua caçadora de cabeças. Belas mulheres que, por meio da sedução, conquistam as cabeças decapitadas que desejam. Erwin Panofsky debate-se para desvendar o enigma pictórico de Judite e Salomé numa tela de Francisco Maffei (PANOFSKY, 2001, p. 59). Mas, não tratamos de uma ou de outra, tratamos de caçadoras de cabeças. 
Salomé fora reinventada pela modernidade que se instaurava e modificava as metrópoles do século XIX (BENJAMIN, 2010). Paris, à época, estava embebida de vida boêmia e prostíbulos (BAKKER; PLUDERMACHER, 2015). Destaca-se, então, a imagem da femme fatale - sedutora, perversa e diabólica - que se vê quase que reengendrada naquele século XIX (DOTTIN-ORSINI, 1997). A personagem bíblica narrada nos evangelhos de Marcos e Matheus fora revisitada pela literatura que lhe concedia novos contornos pelos escritos de Oscar Wilde, Huysmans, Flaubert. A perversidade também consistia em marca das mulheres apresentadas por muitos artistas naquele momento. Cabeças decapitadas foram fartamente apresentadas em imagens, diversas delas atrelavam o feminino ao erótico, fazendo alusão à posição de Georges Bataille (2004), que vincula eroticidade e violência. Era a imagem de uma cabeça separada do corpo nas mãos de belas mulheres de olhos assassinos. Lucrécias, Judites e Salomés (KRISTEVA, 2013) foram fortemente retomadas no século XIX (MORAES, 2002).

Era o anúncio do corpo fragmentado, que figurará amplamente na arte principalmente a partir do século XX. Os oitocentos são os últimos momentos da bela apresentação corpórea mimética feminina nas artes europeias. A representação anatômica do corpo humano alcançara foco a partir do Renascimento e não fora fortemente questionada até o final do século XIX e o inicio do século XX. O corpo humano da morfologia, da anatomia e da dissecação foi apresentado pela imagem de arte desde o Renascimento Italiano até o Neoclassicismo Europeu, podendo-se apontar estes três séculos (XVI, XVII, XVIII) (ARASSE, 2008. p. 553). Contudo, torna-se importante pontuar que, como assinala Daniel Arasse, o tempo da história da arte, bem com o tempo das formas, não é homogêneo e linear (ARASSE, 2008). No mesmo Renascimento Italiano, de maneira mais tímida, já eram ensaiados corpos com a carne aberta, em especial em contextos de histórias sagradas e juízos infernais (DIDI-HUBERMAN, 1999). Contudo, questões dessa fissura, desse desmontar de corpos começam a ser expressivamente levantadas no século XIX. É no decorrer do século XX que desenhar, pintar e modelar corpos não significaria mais captá-los em suas verdades anatômicas (MICHAUD, 2012).

A questão do porquê o Renascimento, que tanto se fixou na construção anatômica do corpo também o apresentou em pedaços é simples: para construir o corpo anatômico pictórico ou escultórico os artistas precisaram abrir os corpos de 
carne e osso. Alberti, em sua Da Pintura (2015) já falava, antes de Leonardo Da Vinci, da abertura de corpos, embora ainda timidamente. Alberti escreve que para se pintar um nu se deveria exercitar a atividade de vestir os ossos com músculos, os músculos com carne e finalmente revestir tudo com pele nua. Ele afirma que o corpo anatômico, o corpo aberto, está para a o nu, assim como o nu está para o corpo vestido.

O corpo fragmentado e aberto fazia parte do repertório daqueles artistas. No século XVIII, já se pode visualizar o corpo fragmentado em cenas de martírio, em especial nos quadros religiosos que permitem aos artistas construções corpóreas que envencilhavam seus exímios trabalhos como anatomistas. A arte no século XVIII abordaria tal corpo inteiro a partir da visão dita científica, fragmenta-se para compreender-se o todo. O Neoclassicismo compreende também a construção corpórea através da herança das artes da Antiguidade Clássica e do Renascimento.

A atitude de especialistas e do público para com o fragmento modifica-se sobremaneira no final do século XVIII e no inicio do século XIX. De certa feita, as esculturas da Antiguidade mutiladas pelo tempo fazem com que o público aprenda a compreender o corpo em sua incompletude. Além do mais, seria difícil compreender o século XVIII sem suas guilhotinas. Para Daniel Arasse, a guilhotina pode ser considerada a primeira máquina de tirar retratos (ARASSE, 1987). Georges Bataille atrela a origem dos museus modernos às mesmas guilhotinas. Para ele, o primeiro museu, no sentido moderno da palavra, foi a Convenção Francesa de 1793, na qual cabeças guilhotinadas foram expostas e eram, de certa maneira, contempladas (BATAILLE, 1988). O fragmento, o corpo apresentado separado de sua cabeça ganha evidencia à época. "As cabeças míticas das Medusas, cortadas por Perseu, ou da de São João Batista, entregue a Salomé sobre uma bandeja de prata, cedem lugar a um contato presente, cotidiano, com as cabeças verdadeiras, sem corpos [...]" (COLI, 2015, p. 183).

Victor Meirelles pinta uma Salomé em 1855 e Pedro Américo, uma Judite em 188o. Nenhuma das duas apresentam-se nuas, cada qual escolhera vestimentas díspares para cobrirem os corpos de suas caçadoras de cabeças. Uma vestida como deusa grega antiga; e a outra, com vestido de orientalismo marcante.

Meirelles pinta sua Salomé com ares essencialmente puristas, A degolação de São João Batista (1855) é a primeira obra que o pintor envia para a Academia de Belas Artes do Rio de 
Janeiro como resultado de sua estada na Europa, especificamente em Roma. A tela destaca-se pela forte influência purista que Meirelles tivera nos primeiros anos em Roma e sublinha as críticas que o pintor recebera de seu mestre - Araújo Porto Alegre - pela abstração e pelo pouco apreço para com as construções anatômicas. Porto Alegre questiona Meirelles, em carta, sobre que diabos era aquela Salomé que não tinha "alegria perversa" (COLI, 1994, p. 225) nem nada da sensual dançarina que conquistou a cabeça que tanto desejara. A crítica pautava-se, sobretudo, no afastamento de Meirelles da pintura neoclássica e na sua aproximação de ideias puristas naquela chegada à Europa.

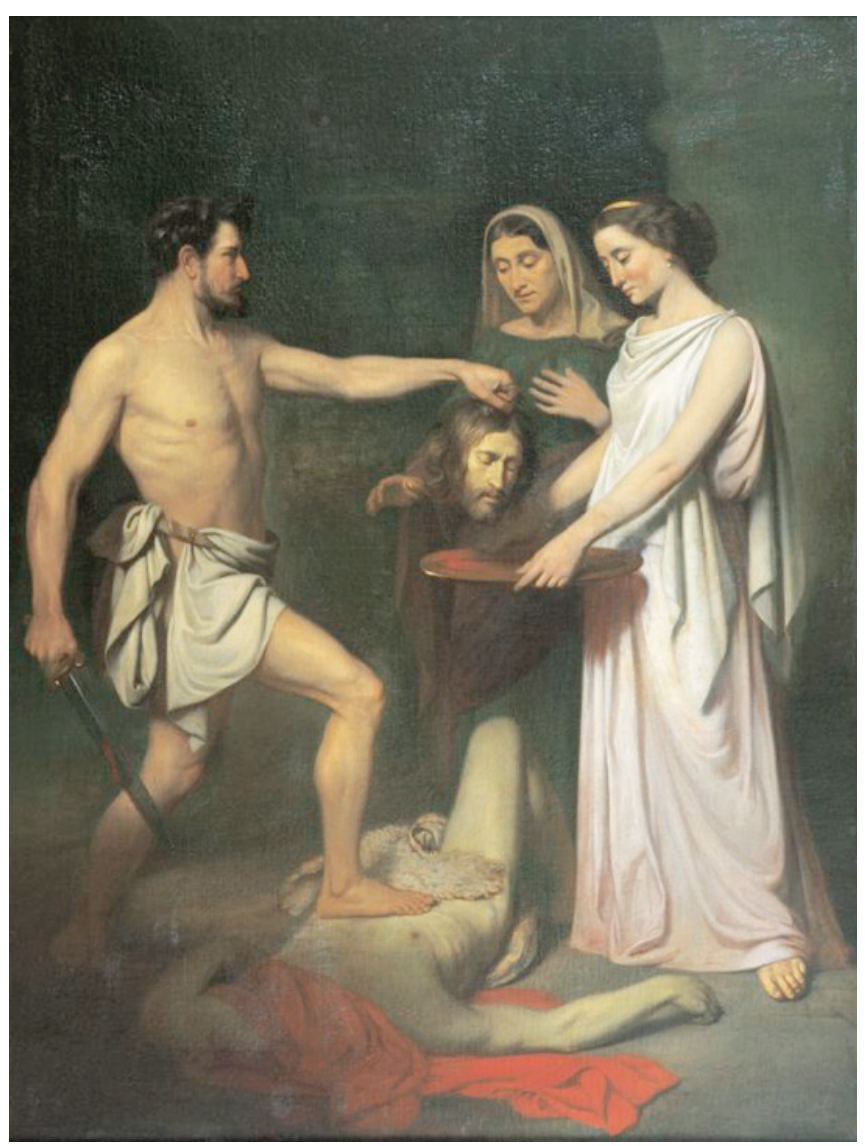

Incontestavelmente Meirelles não nos apresentou uma bela e sensual dançaria. E fora como uma dançarina, sedutora e perversa que Salomé apareceu em diminutas linhas bíblicas.
Figura 8.

Degolação de São João Batista, Victor Meirelles.Óleo sobre tela, $130 \times 96,9 \mathrm{~cm}, 1853$. 
A filha de Herodias e Herodes Filipe protagoniza a história, do século I D.C, em que, após magistral dança a Herodes Antipas pede como prêmio a cabeça de São João Batista. O santo fora executado e sua cabeça entregue em uma bandeja a Salomé.

Alguns anos depois, o pintor simbolista francês, um verdadeiro poeta de Salomé - Gustave Moreau - parece ter pintado como nenhum outro a dançarina bíblica. Mas, na ocasião, Porto Alegre não estava mais vivo - as imagens de Salomé de Moreau teriam lhe causado deleite. Diferentemente dos olhos da dançarina de Moreau, os olhos da Salomé de Meirelles não eram assassinos, eles não apresentavam ganas pela cabeça daquele Santo. Entretanto, Meirelles nos oferece o outro lado daquela moeda. Didi-Huberman lembra-nos que a Servente do Nascimento de São João Batista e a Salomé, que pedira a cabeça decapitada do mesmo santo, são irmãs gêmeas, os dois lados da mesma moeda.

Voltemos à Ninfa de Warburg, a servente de pés ligeiros de Domenico Ghirlandaio. Tal qual a bela "aparição feminina" da Capela dos Tornabuoni, a Salomé de Meirelles fora envolvida num monocromático - agora róseo - vestido. $\mathrm{O}$ tecido marca a draperia própria das Ninfas, visível notadamente nos sarcófagos da Antiguidade. A Salomé de Meirelles vem de muito longe, ele parece apresenta-nos uma deusa grega no exílio, como apresenta-nos Ghirlandaio. Meirelles apresenta uma Salomé como imagem feminina da bela Ninfa envolta num drapeado e clássico vestido róseo. Draperia em movimento que consiste para Warburg, numa privilegiada ferramenta patética (DIDI-HUBERMAN, 2015, p. 45).

Para Roland Recht, a amplitude de ver no mesmo motivo uma energia e sua inversão consiste na grande força do pensamento de Warburg. Essas inversões podem ser visualizadas, tanto nos textos de conferências, quanto no Atlas. "Dos numerosos exemplos expostos nas pranchas de Mnemosyne: a Ninfa portando uma cesta e sua inversão como caçadora de cabeça [...]" (RECHT, 2012, p. 41). A imagem é pensada por Warburg, como campo de forças, nos quais buscava tensões, polaridades. Fora a partir das citadas tensões que ele desenvolvera suas análises sobre as Ninfas - como leitor de Nietzsche, ele conjugava sua Ninfa entre a bipolaridade apolínea e dionisíaca.

Warburg escreve que a servente que levou frutos frescos por ocasião do nascimento do Santo São João Batista é a mesma figura que pediu sua cabeça anos depois. Tratava-se da mesma coisa, eram encarnações possíveis da Ninfa, a fórmula 
do movimento e o pathos fundamental da imagem (DIDI-HUBERMAN, 2015, p. 27) - a criatura amoral por excelência.

A Judite de Judite e Holofernes (1880) de Pedro Américo tem olhos de clemência a Jeová. Três anos após ter pintado sua Judite ao lado da cabeça decapitada de Holofernes, Pedro Américo faria uma das mais afamadas telas de corpo fragmentado na arte brasileira: o cadáver de Tiradentes esquartejado (1893). Enfim, aquelas imagens artísticas do século XIX estavam repletas de cadáveres.

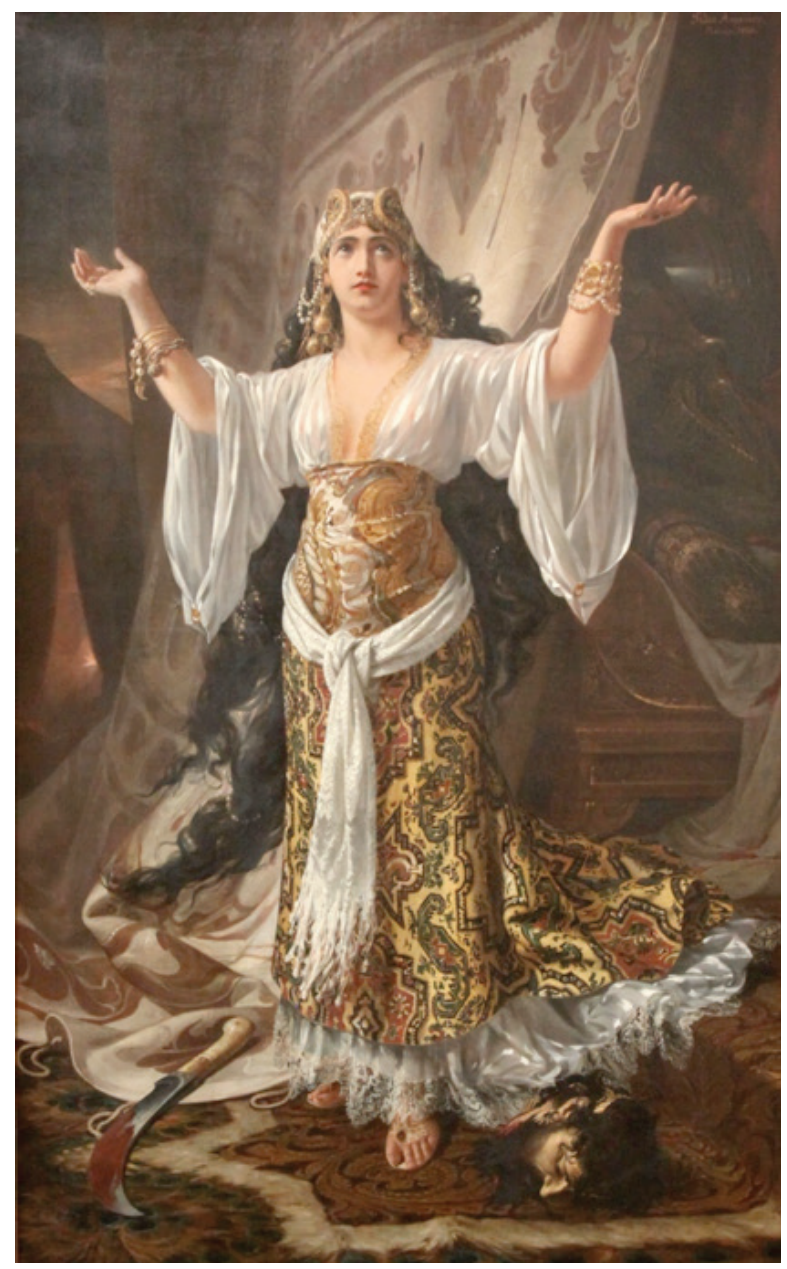

Uma heroína bíblica, apesar de atualmente não constar na Bíblia, tem história que remonta, provavelmente, o século II a. C. Em oposto a Salomé, Judite foi uma heroína: salvara

\section{Figura 9.}

Judite rende graças a Jeová, Pedro Américo. Óleo sobre tela, 229x114, 1880. Museu Nacional de Belas Artes. 
sua cidade - Betúlia - da ocupação dos assírios. Uma sedutora justiceira num ato de virtude heroica. A virtuosa viúva salvou sua cidade matando o homem que seduzira. Botticelli apresentou a personagem com a mesma draperia da Ninfa, que tão bem e repetidamente o fizera em: Judite saindo da tenda de Holofernes (1495) e o Retorno de Judite à Betúlia (1472). Lucas Cranach, por sua vez, apresenta-nos a Judite sempre muitíssimo bem ornada, como a de Pedro Américo, mas envolta nos nobres tecidos e nas formas comuns às mulheres burguesas daquela Renascentista Europa do Norte. E ele fez muitas. Entre tantas Judites de Cranach destaca-se: Judite com a cabeça de Holofernes (1530). Nesta tela, de Cranach pinta uma bela jovem ricamente adornada que exibe uma espada num punho e a cabeça decapitada do tirano em outro.

Pedro Américo apresenta uma figura feminina em primeiro plano. Olhos de clemência dois braços elevados a Jeová. Sua Judite não tem em suas mãos nem a espada nem a cabeça de Holofernes, ambas se encontram no solo sob adornada tapeçaria. A espada ensanguentada de um lado e a cabeça decapitada do outro. Tanto a tenda, quanto as vestimentas de Judite apresentam fortes elementos orientais, como a estampa dos tecidos, as joias, a forma das vestes. Sua caçadora de cabeça apresenta elementos de um orientalismo marcante naquele século XIX francês (PELTRE, 2004). Muitos artistas europeus empreenderam viagens de estudos ao Oriente naquele século XIX (PELTRE, 1995). Para além das obras elaboradas durante essas viagens por esses artistas viajantes, vislumbram-se também fortemente elementos de tal orientalismo em muitas das telas da época, como por exemplo, na já mencionada Aparição de Gustave Moreau, marcadamente uma dançarina oriental (GIL, 2006). Judite de Américo assim como Salomé de Moreau eram apresentações femininas fortemente influenciadas por elementos orientais. Mas do que isso, elas eram mais do que isso, eram belas Ninfas a caçar cabeças.

Nesta montagem de imagens, as Ninfas ganham potência e deixam claro que são o fóssil da vida em movimento o Leiffossil de Warburg. Terminemos, então, com as Ninfas e com a proposição de Georges Didi-Huberman. As Ninfas quase sagradas do Panteão. As eróticas e inquietantes Ninfas foram para muitos lugares em inconstantes tempos. A Ninfa percorre a história da arte como um verdadeiro fóssil em movimento. A donzela com pés ligeiros perpassa e embaralha o tempo. Mostra como escreveu Georges Didi-Huberman, que na imagem não visualizamos o tempo puro. $\mathrm{A}$ imagem é o 
território do anacrônico, e a Ninfa anda, sempre apressada, por ele.

"Ela conjuga uma certa animação de corpos com um certo poderes das almas ("causa interior"), uma certa animação de superfícies com um certo poder do ar ("causa externa”), segundo a expressão escolhida por Warburg em 1893" (DIDI -HUBERMAN, 2015, p. 44). Ninfa é resultado de construção altamente elaborada, ela vai e vem com seu drapeado flutuante, com suas ondulantes e sempre soltas madeixas. Ela é fórmula capaz de moldar num mesmo gesto um corpo, com seu interior e seu exterior. Ela é a forma do próprio desejo, sempre conflituoso, sempre dialético. "A ninfa se encarna, ou seja, é tanto mulher como deusa: Vênus terrestre e Vênus celeste, dançarina e Diana, serva e Vitória, Judite castradora e Anjo feminino, como podemos ver, notadamente ao percorremos as pranchas 46 e 48 do Atlas Mnemosyne" (DIDI-HUBERMAN, 2002, p. 133).

\section{Quatro apresentações femininas - Uma mon- tagem de encarnações possíveis da Ninfa}

Moema, A Carioca, Degolação de São João Batista e Judite rende graças a Jeová são as quatro imagens iniciais dessa pretensa montagem. Uma montagem que versou $O$ corpo feminino, o movimento e a fluidez, como sugere o título deste artigo. Buscou-se tais elementos para analisar, problematizar e sugerir imagens da Ninfa na pintura brasileira do século XIX, como expresso no subtítulo deste mesmo texto. Para tal, foram utilizadas duas preposições warburguinianas: a montagem e a Ninfa.

Aby Warburg não teorizou a montagem (SOMAINI, 2013), ao contrário do que fizera o cineasta soviético Serguei Eisenstein (2002, 2013). Não obstante, em seu Atlas Mnemosyne ele praticou, como poucos, uma história da arte feita a partir de montagens e desmontagens de imagens (DIDI-HUBERMAN, 2010). Colocar imagens em relação, montá-las uma ao lado de outras - porque as imagens não falam de forma isolada - é atividade que sempre insiste Georges Didi-Huberman, o qual concilia Aby Warburg, Serguei Eisenstein e Walter Benjamin em suas proposições de montagens que se reverberam em seus muitos livros, seminários e exposições.

Estas breves páginas ensaiaram montar imagens de Victor Meirelles e Pedro Américo junto a tantas outras imagens de um vasto repertório da história da arte ocidental. Essas ima- 
gens de Meirelles e Américo assinalam um projeto visual para aquela recente nação. Contudo, tais pinturas também nos possibilitam montagens que apontam para outras imagens de outros locais.

Imagens de outros tempos históricos também se conjugam nesta atividade de montar, pois, como bem assinala Daniel Arasse, "todo objeto de arte que já tem um certo grau de existência na história, logo a maior parte das obras de arte, misturam no mínimo três tempos" (ARASSE, 2004, p. 226). Como Didi-Huberman defende, as imagens embaralham o tempo, naquelas este é sempre heterogêneo, sempre anacrônico (DIDI-HUBERMAN, 2013a, p. 32). Pretendeu-se ensaiar uma dupla atividade warburguiniana, através das duas grandes personagens elaboradas por seus trabalhos: o Atlas e a Ninfa. O titã Atlas, que carrega o peso do mundo sobre as costas, fora o nome dado aos painéis negros da memória onde Warburg compôs suas montagens e desmontagens imagéticas. Através de tais painéis que se localizavam na sala oval de sua biblioteca ele pensou e analisou imagens, sempre postas em relação e no plural. A Ninfa é a heroína do Nachleben warburguiniano. Ela aborda duas questões centrais para a compreensão do que é a imagem em Aby Warburg: o pathos/ethos e a pós-vida. Os artistas do Quattrocento reivindicam a Ninfa como uma vitalidade em movimento. Ela não seria apenas uma fórmula iconográfica, mas uma fórmula de intensidade, o poder de fazer visível numa imagem o movimento da vida.

Iniciei este artigo com as questões colocadas a Aby Warburg por André Jolles em 1900. E pretendo fechá-lo com a interrogativa proposta mais de cem anos depois por Georges Didi-Huberman: "Para onde vão as Ninfas sagradas do Panteão?” A resposta à essa pergunta é que as ninfas vão para muitos lugares e para muitos tempos. "Não existe sentido em perguntar onde a ninfa começa seu curso, nem onde ela acaba, pois, a Ninfa designa, para Warburg, a impessoal heroína do Nacheleben - a sobrevivência dessas paradoxais coisas do tempo" (DIDI-HUBERMAN, 2002, p. 45).

NOTAS

1. O presente artigo apresenta-se como fruto de pesquisa de pós-doutoramento desenvolvida junto ao Centre d' Histoire et de Théorie des Arts (CEHTA) da École des Hautes Études en Sciences Sociales (EHESS) de Paris, sob a supervisão do Professor Doutor Georges Didi-Huberman e com bolsa consentida pelo CNPq.

2. Professora visitante junto ao Programa de Pós-Graduação em Arte Visuais (PPAV) da Universidade Federal da Bahia (UFBA) e pós-doutoranda junto ao Instituto de Estudos da Linguagem (IEL) da Universidade Estadual 
de Campinas (Unicamp). E-mail: camposdanielaqueiroz@gmail.com 3. Aborda-se aqui o Pathosformel como conceito de Aby Warburg. Conceito que fora inicialmente desenvolvido na tese sobre o Nascimento de Vênus e a Primavera de Sandro Botticelli, mas assim denominado no texto dedicado a Durer.

4. Utiliza-se aqui os termos ethos apolíneo e pathos dionisíaco com referencia aos escritos do Nascimento da tragédia de Nietzche, os quais foram sobremaneira utilizados nas obras de Aby Warburg, visivelmente em sua tese doutoral.

\section{Referências}

AGAMBEN, Giorgio. Ninfa. Valencia: Pré-textos, 2010. 6op. ARASSE, Daniel. A carne, a graça, o sublime. In: CORBIN, Alan; COURTINE, Jean-Jacques; VIGARELLO, Georges (Dir.). História do Corpo: Da Renascença às Luzes. Petrópolis/RJ: Editora Vozes, 2008. 664 p.

. La guillotine et l'image de la Terreur. Paris: Flamarion, $1987.286 \mathrm{p}$.

. Histoire de penture. Paris: Éditions Denoel, 2004. $368 \mathrm{p}$.

BANN, Stephen. De l'intime à l'idéal: les scènes de famille des années 1840. In: BAKKER, Nienke; PLUDERMACHER, Isolde. Splendeurs \& misères: images de la prostitution, 1850-1910. Catalogue d'exposition. Paris: Musée d'Orsay, Flammarion, 2015. $451 \mathrm{p}$.

BAKKER, Nienke; PLUDERMACHER, Isolde. Splendeurs $\mathcal{E}$ misères: images de la prostitution, 1850-1910. Catalogue d'exposition. Paris: Musée d'Orsay, Flammarion, 2015. $451 \mathrm{p}$.

BATAILLE, Georges. O Erotismo. São Paulo: Editora Arx, 2004. 344 p.

. Ouvres (ou Oeuvres?) completes, t.I. Paris: Gallimard,1988. $689 \mathrm{p}$.

BENJAMIN, Walter. Obras escolhidas. Magia e técnica, arte e política: Ensaios sobre literature e história cultural. São Paulo: Brasiliense, 2010. 256 p.

CARERI, Giovanni. Aby Warburg. Rituel, Pathosformel et forme intermédiaire. L'Homme, n. 165, p. 41-76, 2003/1.

CLARK, Kenneth. $\mathrm{O}$ nu. Um estudo sobre o ideal em arte. Lisboa: Editora Ulisseia, 1956. 402 p.

COLI, Jorge. A batalha de Guararapes de Victor Meirelles $e$ suas relações com a pintura internacional. 1994. 329f. Tese - Departamento de História da Universidade Estadual de Campinas, Campinas, 1994.

. Como estudar a arte brasileira do século XIX. São

Paulo: Editora Senac São Paulo, 2005. 114 p. 
. Le Corps de la Liberté. Essais sur la penture du XIX siècle. Grenoble: ELLUG - MSH-Alpes, Université Grenoble-Alpes, 2015. $277 \mathrm{p}$.

. Fabricação e promoção da brasilidade: arte e questões nacionais. Revue Perspective, n. 2, p. 1-11, 2013.

DIDI-HUBERMAN, Georges. A imagem sobrevivente: história da arte e tempo dos fantasmas segundo AbyWarburg. Rio de Janeiro: Editora Contraponto, 2013 a.

. Blancs soucis. Paris: Minuit, 2013 b.

. Ouvrir Vénus: Nudité, rêve, cruauté. Paris: Gallimard, 1999. $149 \mathrm{p}$.

. L'oeil de l'histoire: Tome 2, Remontages du temps subi. Paris: Minuit, 2010. 250 p. . Ninfa moderna. Essai sur le drape tombe. Paris: Gallimard, 2002. $179 \mathrm{p}$. . Ninfa fluída. Paris: Gallimard, 2015. 211p.

DIJKSTRA, Bram. Les idoles de la perversité. Figures de la femme fatale dans l aculture fin de siècle. Paris: Éditions du Seuil, 1992. 479 p.

DOTTIN-ORSINI, Mireille. Cette femme qu'ils disent fatale. Paris: Grasset et Fasquelle, 1997. 47 p.

DURÃO, Santa Rita. Caramuru: Poema Épico do descobrimento da Bahia. São Paulo: Martin Claret, 2003.

EISENSTEIN, Serguei. Notes pour une histoire générale du cinéma.Paris:afrhc, 2013.

. O sentido do filme. Rio de Janeiro: Zahar, 2002.

FRANZ, Teresinha Sueli. Victor Meirelles e a Construção da Identidade Brasileira. Revista 19E्E20, Rio de Janeiro, v. 2, n. 3, p. 1-10, jul. 2007.

FREEDBERG, David. El poder de las imágenes. Estudios sobre la historia y la teoría de la respuesta. Madrid: Ediciones Cátedra, 2010. 504 p.

GOMBRICH, Ernst Hans; FRITZ, Saxl. Aby Warburg: une biographie intellectuelle. Suivie d'une étude sur l'histoire de la bibliothèque de Warburg. Paris: Klincksieck, 2015. $376 \mathrm{p}$.

GIL, Daniel. Gustave Moreau: sueños de Oriente. Catálogo de exposição, Instituto de Cultura, del 7 de noviembre de 2006 al 7 de enero de 2007]. Madrid: 2007. 222 p.

JOLLES, André. Ninfa Florentina. Fragmento de um projeto sobre as Ninfas. Primeira epístola. In: WARBURG, Aby. Domenico Ghirlandaio. Lisboa: KKYM, 2015.152 p.

KRISTEVA, Julia. Visions capitales. Arts et rituels de la dácapitation. Paris: Éditions Fayard, 2013. 144 P. 
LESCOURRET, Marie Anne. Aby Warburg et la tentation du regard. Paris: Hazan, 2014. 429 p.

MICHAUD, Yves. O corpo e as artes visuais. In: COURBIN, Alan; COURTINI, Jean-Jacques; VIGARELLO, Georges (Org). História do corpo.

MIYOSHI, Alexandre Gaiotto. Moema é morta. 2010. Tese (Doutorado) - Instituto de Filosofia e Ciências Humanas, Universidade Estadual de Campinas, Campinas, 2010..

MORAES, Eliane Robert. O Corpo impossível. São Paulo: Editora Iluminuras, 2002. $213 \mathrm{p}$.

NIETZSCHE, Friedrich. Origem do drama trágico alemão. Belo Horizonte: Autentica, 2007. 336 p.

OLIVEIRA, Claudia de e NERY, Laura. A carioca, de Pedro Américo: alegoria e erotismo no imaginário oitocentista brasileiro. Disponível em: <http://www.ufrgs.br/gthistoriaculturalrs/laura_nery_e_claudia_de_oliveira.html>. 1-11 p. Acesso em: 20 jul. 2016.

A Carioca de Pedro Américo: gênero, raça e miscigenação no Segundo Reinado. Revista Caiana, v. 2, p. 1-9, 2013.

PANOFSKY, Erwin. Significado nas artes visuais. São Paulo: Editora Perspectiva, 2001. 152 p.

PELTRE, Christiene. L'Atelier du voyage: les peintres en Orient au XIXème siècle. Paris: Gallimard, 1995. 118 p. Orientalisme. Paris: Terrail, 2004. 253 p.

POMARÈDE, Vicent. Belles du Louvre. Paris: Éditions de la Martinière, Louvre éditions, 2012. 309 p.

PRAT, Luis-Antoine. Paul Delaroche. Cabinet des dessins. Paris: Édition Musée du Louvre, 2012. 89 p.

RECHT, Roland. L'Atlas Mnémosyne d'Aby Warburg. In: WARBURG, Aby. L’Atlas Mnémosyne. Paris: l'Écarquillé, 2012. $197 \mathrm{p}$.

SCHMITT, Jean-Claude. O corpo das imagens: ensaios sobre a cultura visual na Idade Média. Bauru,SP: EDUSP, 2007. 380 p.

SOMAINI, Antonio. Généalogie, morphologie, anthropologie des images, archéologie des médias. In: EISENSTEIN, Serguei. Notes pour une histoire générale du cinéma. Paris: afrhc, 2013. $300 \mathrm{p}$.

WARBURG, Aby. Atlas Mnemosyne. Madri: Ediciones Akal, 2010. 208 p.

. Domenico Ghirlandaio. Lisboa: Projecto Ymago, KKYM, 2015a. 152 p.

História de fantasmas para gente grande. Rio de Janeiro: Editora Contraponto, 2015b. 417 p. 
Recebido em: 25/01/2017

Aceito em: 31/o8/2017

\section{DANIELA QUEIROZ CAMPOS camposdanielaqueiroz@gmail.com}

Professora visitante junto ao Programa de Pós-graduação em Artes Visuais da Universidade Federal da Bahia. Realizou estágio pós-doutoral pelo Centre d'Histoire et de Théorie des Arts da École des Hautes Études en Sciences Sociales - CEHTA/EHESS - de Paris sob a supervisão do Professor Georges Didi-Huberman e com bolsa do CNPq. Doutora em História pela Universidade Federal de Santa Catarina. 